Article

\title{
Removal and Conversion of Tar in Syngas from Woody Biomass Gasification for Power Utilization Using Catalytic Hydrocracking
}

\author{
Jiu Huang ${ }^{1, *}$, Klaus Gerhard Schmidt ${ }^{2}$ and Zhengfu Bian ${ }^{1}$
}

1 School of Environmental Science and Spatial Informatics, China University of Mining and Technology (CUMT), Xuzhou 221008, China; E-Mail: baiyh@cumt.edu.cn

2 Institute of Energy and Environmental Technology e.V. (IUTA), Duisburg 47229, Germany; E-Mail: k.schmidt@iuta.de

* Author to whom correspondence should be addressed; E-Mail: baiyh@cumt.edu.cn; Tel.: +49-241-41205477; Fax: +86-516-83885057.

Received: 27 June 2011; in revised form: 4 August 2011 / Accepted: 4 August 2011 / Published: 12 August 2011

\begin{abstract}
Biomass gasification has yet to obtain industrial acceptance. The high residual tar concentrations in syngas prevent any ambitious utilization. In this paper a novel gas purification technology based on catalytic hydrocracking is introduced, whereby most of the tarry components can be converted and removed. Pilot scale experiments were carried out with an updraft gasifier. The hydrocracking catalyst was palladium (Pd). The results show the dominant role of temperature and flow rate. At a constant flow rate of $20 \mathrm{Nm}^{3} / \mathrm{h}$ and temperatures of $500{ }^{\circ} \mathrm{C}, 600{ }^{\circ} \mathrm{C}$ and $700{ }^{\circ} \mathrm{C}$ the tar conversion rates reached $44.9 \%$, $78.1 \%$ and $92.3 \%$, respectively. These results could be increased up to $98.6 \%$ and $99.3 \%$ by using an operating temperature of $700{ }^{\circ} \mathrm{C}$ and lower flow rates of $15 \mathrm{Nm}^{3} / \mathrm{h}$ and $10 \mathrm{Nm}^{3} / \mathrm{h}$. The syngas quality after the purification process at $700{ }^{\circ} \mathrm{C} / 10 \mathrm{Nm}^{3} / \mathrm{h}$ is acceptable for inner combustion (IC) gas engine utilization.
\end{abstract}

Keywords: biomass gasification; tar conversion; catalytic hydrocracking 


\section{Introduction}

Biomass such as forest, agricultural and organic processing residues can be converted into commercial products via thermo-chemical processes [1-5]. Biomass contributes ca. 14\% of energy supply around the World, while in some developed countries, its contribution ranges from $40 \%$ to $50 \%$ [5]. Because of its renewability, biomass is considered to be one of major potential energy sources in the future [6-8]. Over the last two decades, special attention has been paid to the conversion of residual biomasses and renewable materials into fuels for power machines [9-11]. Energy in biomass comes from solar energy. Biological conversion of low-value lignocelluloses biomass still faces challenges of low economy and efficiency [1]. The characteristic of biomass is its huge amount and relative low energy content, which make any long distance transportation of biomasses to be uneconomical. Combustion, pyrolysis and gasification are three main thermo-chemical conversion methods used for biomass, which is traditionally combusted to supply heat and power for the process industry. The net efficiency for electricity generation from biomass combustion is usually low, ranging from $20 \%$ to $40 \%$ [2]. The amount of biomass co-fired in existing combustors is usually limited to $5-10 \%$ of the total feedstock due to the concerns about plugging of the existing coal feed systems [3]. Pyrolysis converts biomass to bio-oil in the absence of oxygen. The limited uses and difficulty in downstream processing of bio-oil have restricted the wide application of biomass pyrolysis technology [4]. Besides the above mentioned thermo-chemical processes, gasification of biomass and its residues is a promising technology now and in the future. Gasification converts biomass through partial oxidation into a gaseous mixture of syngas (synthesis gas) consisting of hydrogen (10-20\%), carbon monoxide (15-30\%), methane (2-4.5\%), carbon dioxide (5-15\%), nitrogen (45-60\%) and water vapour (6-8\%). In recent years biomass gasification has attracted huge interest by producing syngas which can be easily transported and utilized in different power facilities [12,13]. Biomass gasification converts the intrinsic chemical energy in the biomass into combustible gas. The produced syngas can be standardized in its quality and it is easier and more versatile to use than the original biomass e.g., it can be used for inner combustion (IC) gas engines and gas turbines, or used as a chemical feedstock to produce liquid fuels and chemicals [14].

The state of the art for gasification is the fixed bed gasifier with updraft and downdraft operation [15]. Biomass snygas contains high concentrations of tarry compounds and particles, which must be purified before its utilization. The tars consist of a range of oxygenated hydrocarbons and hydro-carbons, typically containing aromatic, polyaromatic, and furanic backbone structures, with aliphatic and oxygenated functional groups (acids, aldehydes, ketones, and alcohols) attached to the backbone [16]. These tars are notorious for condensing and subsequently polymerizing on downstream equipment such as compressors and IC gas engine surfaces if the gas is sufficiently cooled $[8,16]$. The common facility for syngas utilization in Germany is the IC gas cogeneration engine [17]. Its specification is an equivalent tar concentration lower than $50 \mathrm{mg} / \mathrm{Nm}^{3}$. This value can only be achieved by enhanced gas purification, since the typical tar concentrations in syngas are always $0.1-6 \mathrm{~g} / \mathrm{Nm}^{3}$ for downdraft gasifiers and $10-100 \mathrm{~g} / \mathrm{Nm}^{3}$ for updraft gasifiers $[17,18]$.

Gas purification can be done by dry or wet processes. Cooling down below the dew point of the gaseous by products leads to condensates, mostly tar, which adheres to all inner surfaces of the system. A side effect of this process is an effective removal of dust particles. Wet systems are mainly 
absorption based processes where a solvent dissolves the tar products. The process is carried out in scrubber systems with parallel mist elimination [15]. Both techniques have the same inevitable disadvantages: recovery of solvent and preparation boost cost. Tar condensates and eluant must be treated in order to avoid contamination.

This research work is an experimental feasibility study for a catalytic hydrocracking of tar by-products, including an increase of the calorific value of biomass syngas. Fuel feed is woody biomass. Palladium $(\mathrm{Pa})$ is the catalyst for tar cracking and conversion. All processes are implemented in a reactor downstream of an updraft gasifier. Experiments and measurements are focused on the effects of catalyst temperatures and syngas flow rates. Sampling is done from raw gas and from gas after treatment. Samples are analyzed by flash-evaporation gas chromatography. The results show the efficiency of tar removal and conversion and an increase of high caloric value (HCV).

\section{Catalytic Hydrocracking}

Catalytic hydrocracking has been applied in oil refineries for several decades. Basically, the catalytic hydrocracking process cracks the high-boiling, high molecular weight oxygenates, phenolics, ethers, polyaromatic hydrocarbons (PAH) and large PAHs into lower-boiling, lower molecular weight olefinic and aromatic hydrocarbons and then hydrogenates them [19]; the high-boiling, high molecular weight paraffinic hydrocarbons can also be cracked into lower-boiling, lower molecular weight paraffinic hydrocarbons [20]. By using the catalytic hydrocracking process the tar levels in biomass syngas can be significantly reduced and partly converted into additional fuels for power machines, since the decomposition processes of tar are similar to those of crude oil refining [15,21]. Any sulfur, nitrogen and oxygen present in the hydrocracking feedstock are also hydrogenated to a large extent and form gaseous hydrogen sulfide $\left(\mathrm{H}_{2} \mathrm{~S}\right)$, ammonia $\left(\mathrm{NH}_{3}\right)$ and water vapor, which are subsequently removed. The result is that the hydrocracking products are essentially free of sulfur and nitrogen impurities and consist mostly of paraffinic and naphthenic hydrocarbons. For example during the hydrocracking process hydrodecyclization and monoaromatics hydrogenation reactions will take place, like [20,22,23]:

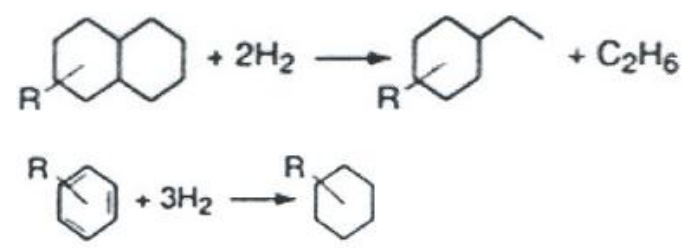

Hydrodesulphurization and hydrodenitrogenation reactions will also the take place, like:

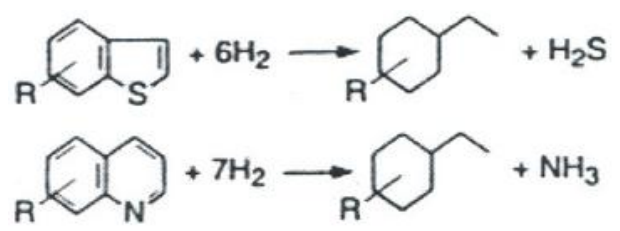

also the hydrodeoxygenation reaction will take place, like:

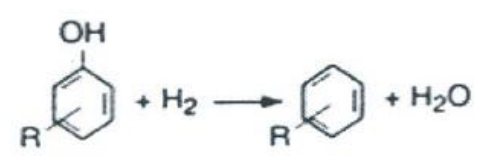


and the hydrocracking of paraffinic hydrocarbons will also take place:

$$
C_{n} H_{2 n+2}+H_{2} \rightarrow C_{a} H_{2 a+2}+C_{b} H_{2 b+2} \quad(a+b=n)
$$

Generally, the hydrocracking conversion process is exothermic. The hydrogen which is consumed through by hydrocracking is produced by the carbon steam reaction and water - gas shift reaction during the gasification process [17]:

$$
\begin{aligned}
& \mathrm{C}+\mathrm{H}_{2} \mathrm{O}=\mathrm{CO}+\mathrm{H}_{2} \quad \Delta \mathrm{H}_{298 \mathrm{~K}}=131.3 \mathrm{~kJ} / \mathrm{mol} \\
& \mathrm{CO}+\mathrm{H}_{2} \mathrm{O}=\mathrm{CO}_{2}+\mathrm{H}_{2} \quad \Delta \mathrm{H}_{298 \mathrm{~K}}=-41 \mathrm{~kJ} / \mathrm{mol}
\end{aligned}
$$

Therefore there is no need for additional hydrogen.

\section{Experimental Setup}

\subsection{Fuel for Gasification}

The source material for our gasification experiments was a mixture of shredded woody biomass like limbs, wood pieces, bark, pine balls and other cut grove (Figure 1a). It was pre-dried in the open air to reduce wood moisture. The main components are carbon $(\mathrm{C})$, hydrogen $(\mathrm{H})$, oxygen $(\mathrm{O})$, and nitrogen (O) of varying concentration, according to its type and location of collection. The average calorific value is about $16.6 \mathrm{~kJ} / \mathrm{g}$. The average moisture content is about $8.9 \%$.

Figure 1. (a) Biomass fuel for gasification; and (b) Updraft gasifier.

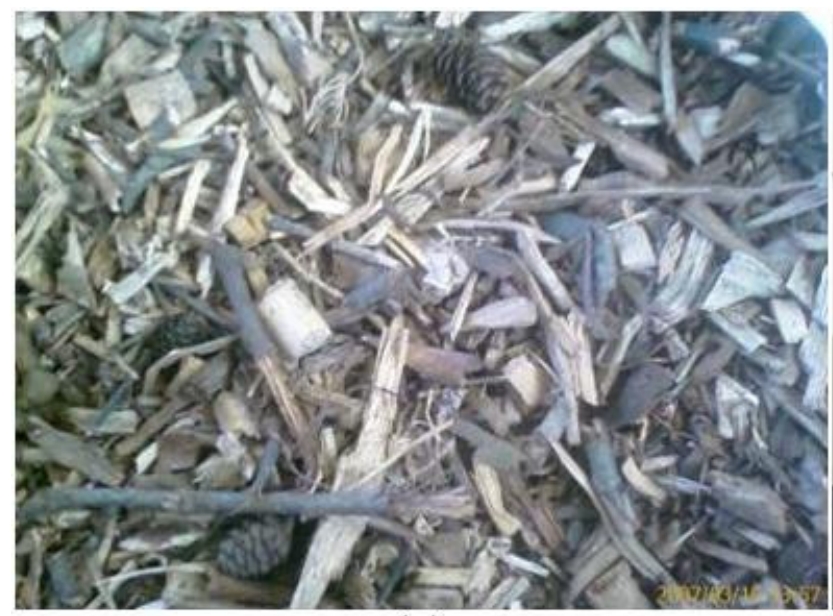

(a)

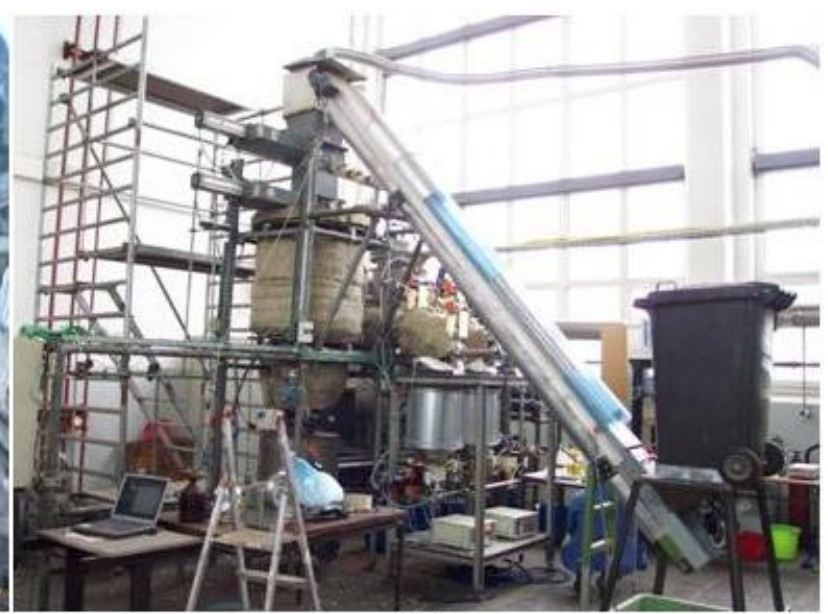

(b)

\subsection{Facilities and Equipment}

Gasification was carried out in an updraft gasifier of the IUTA Institute. Its thermal output is about $100 \mathrm{~kW}$ (Figure 1b). The working flow chart shown in Figure 2 [15] should be self-explanatory. The whole facility was controlled by SPS and WinCC systems. As shown in Figure 2, three Ni/Cr-Ni/Si thermocouples were installed inside the gasifier and nine thermocouples were installed on the wall of gasifier for temperature measurements. Gas concentrations in raw gas (4) and purified gas (5) were analyzed online by non-dispersive infrared sensors (NDIR) and a thermal conductivity detector (TCD) 
which could be switched between (4) and (5). The components measured were $\mathrm{CO}, \mathrm{CO}_{2}, \mathrm{H}_{2}, \mathrm{CH}_{4}$ and $\mathrm{O}_{2}$. Sampling process is described in Section 4.

Figure 2. Flow chart of the updraft gasifier.

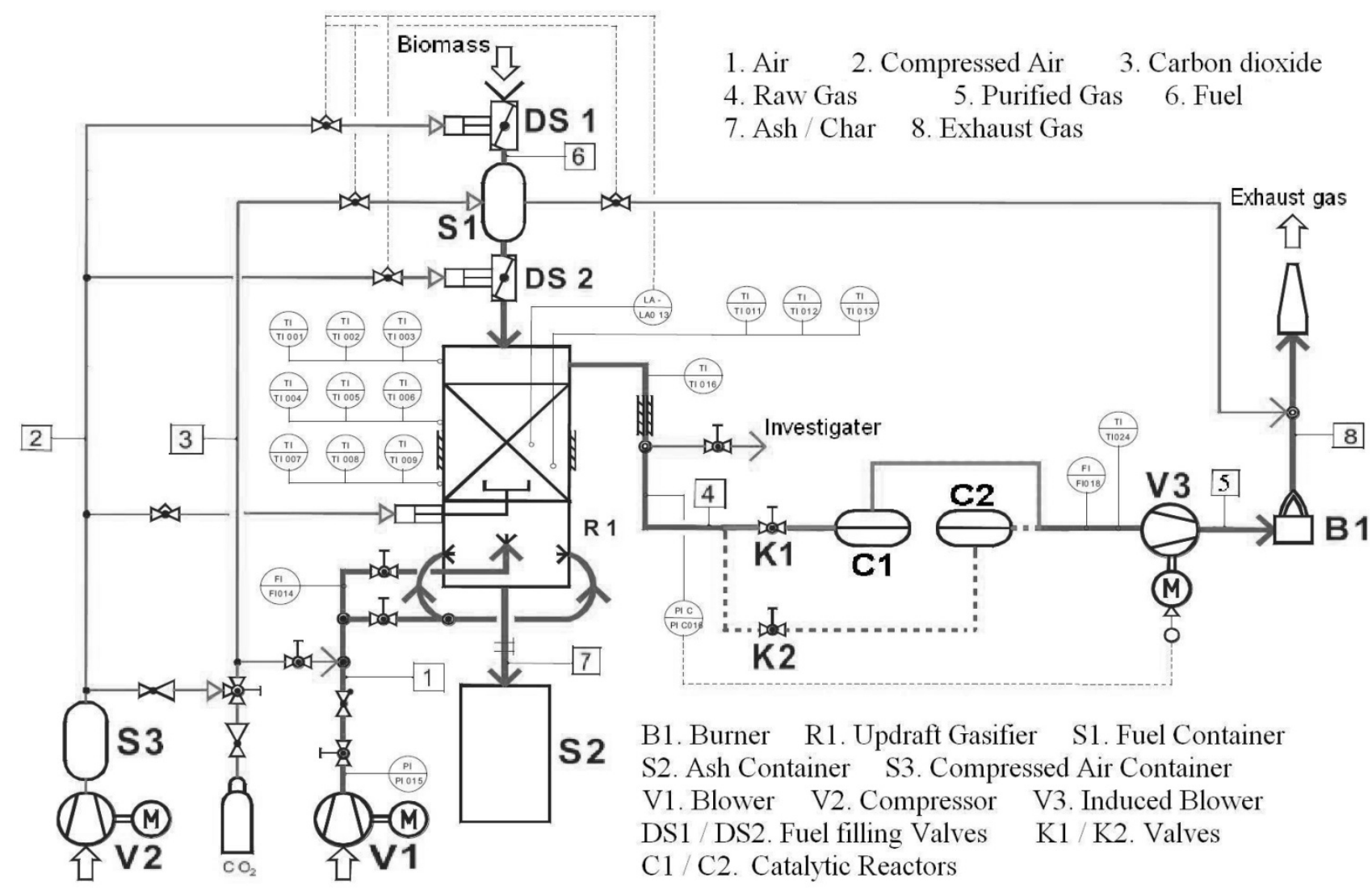

\subsection{Catalyst and Catalytic Reactor}

The syngas taken off at the top of the reactor showed quite high tar concentrations, but low dust acceptable for catalytic hydrocracking. The catalyst for this reaction is made from stainless steel turnings arising as waste during machining in industry. The turnings are in the range of 5 to $10 \mathrm{~mm}$ (Figure 3a) and were electrochemically plated with palladium (Pd).

Reactor dimensions are $200 \mathrm{~mm}$ diameter and total height 1,100 $\mathrm{mm}$, the length of the catalyst bed is $500 \mathrm{~mm}$. The catalyst capacity is 20 liters or about $20 \mathrm{~kg}$ of turnings with a load of $10 \mathrm{~g} \mathrm{Pd}$. The reactor was equipped with electrical heating systems inside (heater rods $3 \times 1.2 \mathrm{~kW}$ ) and outside (heating tapes $2 \times 2 \mathrm{~kW}$ ). The design is shown in Figure $3 \mathrm{c}$.

The hydrocracking process was carried out at low syngas pressures of -10 to -20 mbar. This is in contrast to hydrocracking processes in oil refinery where high pressures up to 200 bar are applied to shift the Boudouard reaction and hydrocarbon decomposition reactions in order to lower soot formation [19,24]. In this research, we experienced soot formation which accumulates on the surface of the turnings (Figure $3 \mathrm{~b}$ ) causing catalyst deactivation. To reactivate it the catalyst reactor can be also operated as an oxidation reactor. The soot was oxidized by air forming $\mathrm{CO}_{2}$. For this process the reactor was switched to a secondary circuit. To achieve continuous operation two reactors are provided. During the experiments each reactor had 15 to $20 \mathrm{~min}$ of operation and $10 \mathrm{~min}$ for reactivation. 
Figure 3. (a) Catalyst pieces; (b) Deactivated catalyst; and (c) Reactor for catalytic hydrocracking.

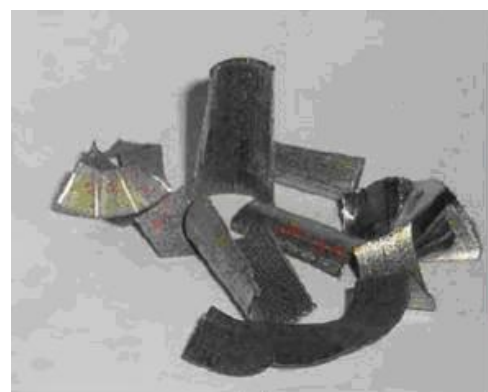

(a)

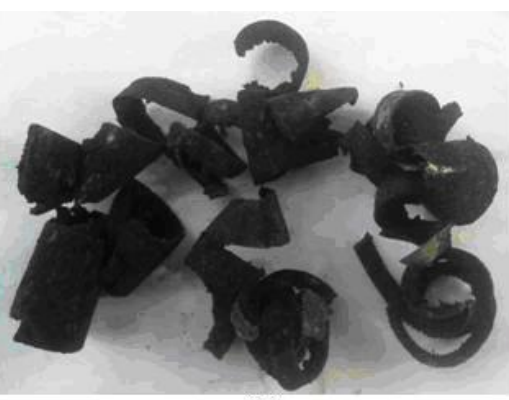

(b)

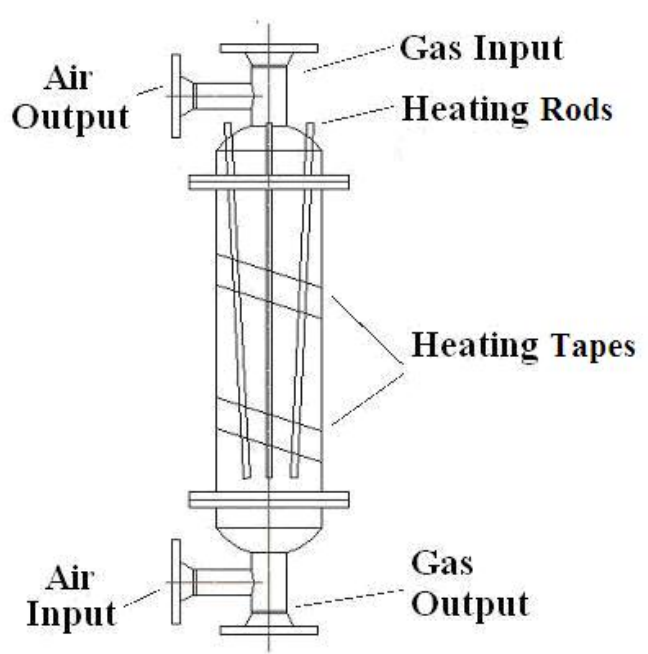

(c)

As shown in Figure 3c, during hydroracking process the "Air input" and "Air output" valves were closed and syngas entered the reactor through "Gas Input", where it came into contact with the heated catalysts and finally flew out of the reactor through "Gas output". During the catalyst reactivation process the "Gas Input" and "Gas output" valves were closed and air with a pressure of about 4 bar was fed into the reactor through "Air Input"; then the air consumed the soot on the surface of the splinters and then flew out of the reactor through "Air output" as exhaust gas.

\section{Sampling and Analysis}

\subsection{Sampling of Tar in Syngas}

Gas samples were taken simultaneously from the raw gas before entering the catalyst reactor and from purified gas leaving the reactor, as shown in Figure 4. The sampling procedure was the same for both. Each line consists of the absorption unit and the facility for measuring the volume flow. Three absorption traps were provided in line with $225 \mathrm{~mL}$ tetrahydrofuran (THF) as absorption fluid ( $75 \mathrm{~mL} /$ trap). The traps were cooled down to $-20{ }^{\circ} \mathrm{C}$ by a cryogenic bath of ice $/ \mathrm{NaCl}$ avoiding vaporization of THF. The sampling process is shown in Figure 4. 
Figure 4. Sampling processes of syngas before and after hydrocracking.

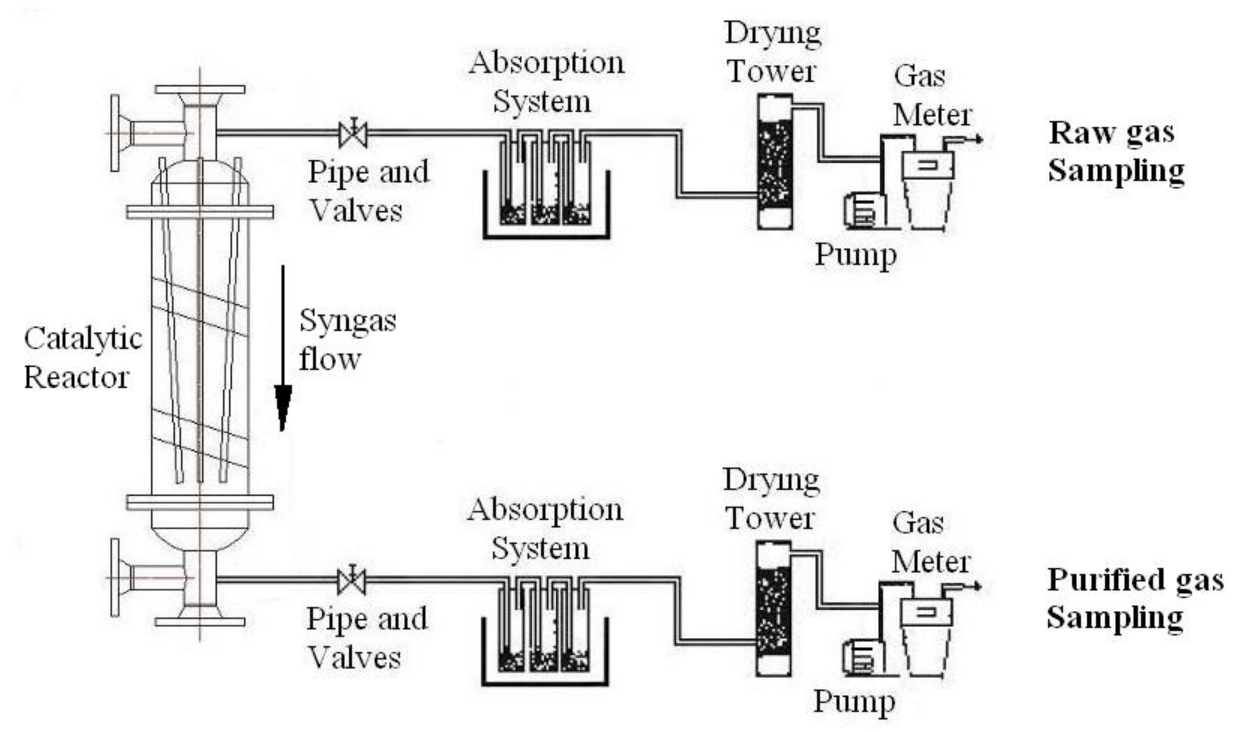

\subsection{Analysis of Tar Samples}

The samples were analyzed for tar components by simulated distillation and flash-evaporation gas-chromatography (FE-GC). Evaporation and detector temperature were $450{ }^{\circ} \mathrm{C}$. The GC column was operated from $50{ }^{\circ} \mathrm{C}$ up to $450{ }^{\circ} \mathrm{C}$. The boiling points of hydrocarbons in purified syngas range from 40 to $440{ }^{\circ} \mathrm{C}$ depending on their molecular weights. Hence the distillation process for this study was split into 23 segments for molecular weights from $C_{7}$ to $C_{29}$ (Table 1) [14].

Table 1. Distillation fractions and their corresponding molecule weights (as C-number).

\begin{tabular}{|c|c|c|c|c|c|}
\hline $\begin{array}{c}\text { Distillation } \\
\text { Fractions } \\
\end{array}$ & $\begin{array}{c}\text { Molecular } \\
\text { Weights }\end{array}$ & Boiling Points $\left({ }^{\circ} \mathrm{C}\right)$ & $\begin{array}{c}\text { Distillation } \\
\text { Fractions } \\
\end{array}$ & $\begin{array}{c}\text { Molecular } \\
\text { Weights }\end{array}$ & $\begin{array}{c}\text { Boiling } \\
\text { Points }\left({ }^{\circ} \mathrm{C}\right)\end{array}$ \\
\hline D01 & $<\mathrm{C}_{7}$ & $\leq 98$ & D13 & $\mathrm{C}_{19}$ & $\begin{array}{l}>317 \\
\leq 330\end{array}$ \\
\hline D02 & $\mathrm{C}_{8}$ & $\begin{array}{l}>98 \\
\leq 126\end{array}$ & D14 & $\mathrm{C}_{20}$ & $\begin{array}{c}>330 \\
\leq 342.7\end{array}$ \\
\hline D03 & $\mathrm{C}_{9}$ & $\begin{array}{l}>126 \\
\leq 151\end{array}$ & D15 & $\mathrm{C}_{21}$ & $\begin{array}{l}>342.7 \\
\leq 356.5\end{array}$ \\
\hline D04 & $\mathrm{C}_{10}$ & $\begin{array}{l}>151 \\
\leq 174\end{array}$ & D16 & $\mathrm{C}_{22}$ & $\begin{array}{c}>356.5 \\
\leq 367\end{array}$ \\
\hline D05 & $\mathrm{C}_{11}$ & $\begin{array}{l}>174 \\
\leq 196\end{array}$ & D17 & $\mathrm{C}_{23}$ & $\begin{array}{l}>367 \\
\leq 380\end{array}$ \\
\hline D06 & $\mathrm{C}_{12}$ & $\begin{array}{l}>196 \\
\leq 217\end{array}$ & D18 & $\mathrm{C}_{24}$ & $\begin{array}{c}>380 \\
\leq 391.3\end{array}$ \\
\hline D07 & $\mathrm{C}_{13}$ & $\begin{array}{l}>217 \\
\leq 234\end{array}$ & D19 & $\mathrm{C}_{25}$ & $\begin{array}{l}>391.3 \\
\leq 401.9\end{array}$ \\
\hline D08 & $\mathrm{C}_{14}$ & $\begin{array}{l}>234 \\
\leq 253\end{array}$ & D20 & $\mathrm{C}_{26}$ & $\begin{array}{l}>401.9 \\
\leq 412.2\end{array}$ \\
\hline D09 & $\mathrm{C}_{15}$ & $\begin{array}{l}>253 \\
\leq 270\end{array}$ & D21 & $\mathrm{C}_{27}$ & $\begin{array}{c}>412.2 \\
\leq 442\end{array}$ \\
\hline
\end{tabular}


Table 1. Cont.

\begin{tabular}{cccccc}
\hline $\begin{array}{c}\text { Distillation } \\
\text { Fractions }\end{array}$ & $\begin{array}{c}\text { Molecular } \\
\text { Weights }\end{array}$ & Boiling Points $\left({ }^{\circ} \mathbf{C}\right)$ & $\begin{array}{c}\text { Distillation } \\
\text { Fractions }\end{array}$ & $\begin{array}{c}\text { Molecular } \\
\text { Weights }\end{array}$ & $\begin{array}{c}\text { Boiling } \\
\text { Points }\left({ }^{\circ} \mathbf{C}\right)\end{array}$ \\
\hline \multirow{2}{*}{ D10 } & $\mathrm{C}_{16}$ & $>270$ & $\mathrm{D} 22$ & $\mathrm{C}_{28}$ & $>442$ \\
& & $\leq 287$ & & & $\leq 431.6$ \\
$\mathrm{D} 11$ & $\mathrm{C}_{17}$ & $>287$ & $\mathrm{D} 23$ & $\mathrm{C}_{29}$ & $>431.6$ \\
& & $\leq 302$ & & $\leq 440.8$ \\
$\mathrm{D} 12$ & $\mathrm{C}_{18}$ & $>302$ & & & \\
\hline
\end{tabular}

For the chromatic evaluation peak areas were used and tar concentrations according to the tar distillation fractions in both raw and purified syngas assigned.

\subsection{Tarry Impurities in IC Engines}

Undesired tarry compounds in IC engines have boiling points higher than $200{ }^{\circ} \mathrm{C}$. Hydrocarbons whose boiling points are lower than $200{ }^{\circ} \mathrm{C}$ contribute as additional fuels, thus increasing the calorific value of syngas. Hence the tar distillation fractions D01-D05 are not considered to be impurities. The actual tar in purified gas is represented by all the compounds within the considered distillation fractions from D06 to D23.

\section{Results and Discussion}

\subsection{Results for Different Temperatures at a Fixed Flow Rate of $20 \mathrm{Nm}^{3} / \mathrm{h}$}

These experiments were carried out at gasification temperatures from 900 to $950{ }^{\circ} \mathrm{C}$. The syngas temperature at the outlet was 200 to $300{ }^{\circ} \mathrm{C}$. The fuel input was controlled keep the stoichiometric air ratio $\lambda$ in the range of 0.15 to 0.2 . Under these conditions the main composition of raw gas was:

CO $18-23 \%$,

$\mathrm{CH}_{4} 3-12 \%$,

$\mathrm{H}_{2} 8-10 \%$,

$\mathrm{CO}_{2} 7-11 \%$.

Additionally nitrogen and traces of oxygen were present. The tar concentration varied from 10 to $25 \mathrm{~g} / \mathrm{Nm}^{3}$. In order to find the appropriate operation temperature of the catalytic reactor screening experiments were carried out [19]. This was done at 500,600 and $700{ }^{\circ} \mathrm{C}$ under a constant flow rate of $20 \mathrm{Nm}^{3} / \mathrm{h}$. Hydrocracking processes were not started until the gasifier had reached a stable state (about $120 \mathrm{~min}$ ). Sampling started $30 \mathrm{~s}$ later after the snygas had entered the reactor with a constant flow rate of $2.5 \mathrm{~L} / \mathrm{min}$ over a period of about $13 \mathrm{~min}$. The results for the conversion of tarry compounds are given in Table 2 .

As can be seen, the fractions D15-D23 were not found either in raw or in purified gas. We have to look for fractions D06-D14. The overall tar conversion increased with catalyst temperature from $44.9 \%$ to $78.1 \%$ and $92.3 \%$. The overall tar concentrations then were about $1.4 \mathrm{~g} / \mathrm{Nm}^{3}$ at $500{ }^{\circ} \mathrm{C}$, 
$0.8 \mathrm{~g} / \mathrm{Nm}^{3}$ at $600{ }^{\circ} \mathrm{C}$ and $0.3 \mathrm{~g} / \mathrm{Nm}^{3}$ at $700{ }^{\circ} \mathrm{C}$ and these reductions of tar were not yet low enough for use in IC engine.

Table 2. Conversion of tarry compounds under flow rate of $20 \mathrm{Nm}^{3} / \mathrm{h}$.

\begin{tabular}{|c|c|c|c|c|c|c|c|}
\hline \multirow{3}{*}{$\begin{array}{l}\text { Distillation } \\
\text { fractions }\end{array}$} & \multirow{3}{*}{$\begin{array}{c}\text { Boiling } \\
\text { Points } \\
\left({ }^{\circ} \mathrm{C}\right) \\
\end{array}$} & \multicolumn{6}{|c|}{ Tar concentration in both raw and purified gas $\left(\mathrm{g} / \mathrm{Nm}^{3}\right)$} \\
\hline & & \multicolumn{2}{|c|}{$1^{\text {st }}$ Experiment $\left(500^{\circ} \mathrm{C}\right)$} & \multicolumn{2}{|c|}{$2^{\text {nd }}$ Experiment $\left(600^{\circ} \mathrm{C}\right)$} & \multicolumn{2}{|c|}{$3^{\text {rd }}$ Experiment $\left(700^{\circ} \mathrm{C}\right)$} \\
\hline & & Raw gas & Purified gas & Raw gas & Purified gas & Raw gas & Purified gas \\
\hline D01 & $\leq 98$ & 6.134 & 5.146 & 7.891 & 4.301 & 7.516 & 1.581 \\
\hline D02 & $\begin{array}{l}>98 \\
\leq 126\end{array}$ & 1.3 & 0.42 & 2.712 & 0.618 & 4.407 & 0.292 \\
\hline D03 & $\begin{array}{l}>126 \\
<151\end{array}$ & 0.547 & 0.171 & 2.035 & 0.498 & 2.912 & 0.583 \\
\hline D04 & $\begin{array}{l}>151 \\
\leq 174\end{array}$ & 0.523 & 0.223 & 1.084 & 0.338 & 1.708 & 0.273 \\
\hline D05 & $\begin{array}{l}>174 \\
\leq 196\end{array}$ & 0.534 & 0.118 & 1.155 & 0.196 & 1.018 & 0.175 \\
\hline D06 & $\begin{array}{l}>196 \\
\leq 217\end{array}$ & 0.258 & 0.253 & 1.000 & 0.126 & 1.116 & 0.131 \\
\hline D07 & $\begin{array}{l}>217 \\
\leq 234\end{array}$ & 0.453 & 0.153 & 1.071 & 0.167 & 0,886 & 0.049 \\
\hline D08 & $\begin{array}{l}>234 \\
\leq 253\end{array}$ & 0.144 & 0.102 & 0.552 & 0.058 & 0.860 & 0.048 \\
\hline D09 & $\begin{array}{l}>253 \\
\leq 270\end{array}$ & 0.089 & 0.040 & 0.348 & 0.021 & 0.194 & 0.032 \\
\hline D10 & $\begin{array}{l}>270 \\
\leq 287\end{array}$ & 1.118 & 0.878 & 0.473 & 0.415 & 0.311 & 0.014 \\
\hline D11 & $\begin{array}{l}>287 \\
\leq 302\end{array}$ & 0.004 & 0.006 & 0.078 & No trace & 0.137 & 0.004 \\
\hline D12 & $\begin{array}{l}>302 \\
\leq 317\end{array}$ & 0.009 & No trace & 0.031 & No trace & 0.089 & No trace \\
\hline D13 & $\begin{array}{l}>317 \\
\leq 330\end{array}$ & No trace & No trace & 0.019 & No trace & 0.018 & No trace \\
\hline D14 & $\begin{array}{l}- \\
>330 \\
\leq 342.7\end{array}$ & No trace & No trace & 0.017 & No trace & 0.004 & No trace \\
\hline Total & - & 10.87 & 7.75 & 18.47 & 6.738 & 21.18 & 3.18 \\
\hline $\begin{array}{l}\text { Tar in gas } \\
\text { engine } \\
\text { D06-D23 }\end{array}$ & - & 2.075 & 1.432 & 3.598 & 0.787 & 3.615 & 0.278 \\
\hline $\begin{array}{c}\text { Conversion } \\
\text { D06-D23 }\end{array}$ & - & & $\%$ & & $8.1 \%$ & & $3 \%$ \\
\hline
\end{tabular}

\subsection{Variation of Flow Rate at Operation Temperature $700{ }^{\circ} \mathrm{C}$}

Another factor which can affect tar conversion is the syngas flow rate, which determines the extent of contact between catalysts and tarry compounds. Lowering the flow rate and increasing the residence time in the reactor is one method to enhance the conversion effect. At the same operating temperature 
of $700{ }^{\circ} \mathrm{C}$ as in the last experiment before, the tar concentration in purified gas had been reduced to $0.278 \mathrm{~g} / \mathrm{Nm}^{3}$, which was better than the conversions at $500{ }^{\circ} \mathrm{C}$ and $600{ }^{\circ} \mathrm{C}$. Hence the flow rate was reduced from 20 to 15 and further to $10 \mathrm{Nm}^{3} / \mathrm{h}$ at $700{ }^{\circ} \mathrm{C}$. The hydrocracking processes were not started until the gasifier had reached a stable state (about $150 \mathrm{~min}$ ). Sampling started $30 \mathrm{~s}$ later after the snygas had entered the reactor with constant flow rate of $2.5 \mathrm{~L} / \mathrm{min}$ over periods of about $14.5 \mathrm{~min}$ and 11.5 min respectively. The results for the conversion of tarry compounds are given in Table 3 .

Table 3. Conversion of tarry compounds at catalyst bed temperature of $700{ }^{\circ} \mathrm{C}$.

\begin{tabular}{|c|c|c|c|c|c|c|c|}
\hline \multirow{3}{*}{$\begin{array}{l}\text { Distillation } \\
\text { fractions }\end{array}$} & \multirow{3}{*}{$\begin{array}{l}\text { Boiling } \\
\text { Points } \\
\left({ }^{\circ} \mathrm{C}\right)\end{array}$} & \multicolumn{6}{|c|}{ Tar concentration in both raw and purified gas $\left(\mathrm{g} / \mathrm{Nm}^{3}\right)$} \\
\hline & & \multicolumn{2}{|c|}{$\begin{array}{c}3^{\text {rd }} \text { Experiment } \\
\left(20 \mathrm{Nm}^{3} / \mathrm{h}\right)\end{array}$} & \multicolumn{2}{|c|}{$\begin{array}{c}4^{\text {th }} \text { Experiment } \\
\left(15 \mathrm{Nm}^{3} / \mathrm{h}\right)\end{array}$} & \multicolumn{2}{|c|}{$\begin{array}{c}5^{\text {th }} \text { Experiment } \\
\left(10 \mathrm{Nm}^{3} / \mathrm{h}\right)\end{array}$} \\
\hline & & Raw gas & Purified gas & Raw gas & Purified gas & Raw gas & Purified gas \\
\hline D01 & $\leq 98$ & 7.516 & 1.581 & 6.712 & 1.845 & 6.171 & 1.310 \\
\hline D02 & $\begin{array}{l}>98 \\
\leq 126\end{array}$ & 4.407 & 0.292 & 1.528 & 0.854 & 2.027 & 0.717 \\
\hline D03 & $\begin{array}{l}>126 \\
\leq 151\end{array}$ & 2.912 & 0.583 & 2.359 & 0.190 & 2.053 & 0.217 \\
\hline D04 & $\begin{array}{l}>151 \\
\leq 174\end{array}$ & 1.708 & 0.273 & 1.742 & 0.152 & 1.620 & 0.177 \\
\hline D05 & $\begin{array}{l}>174 \\
\leq 196\end{array}$ & 1.018 & 0.175 & 1.600 & 0.172 & 1.301 & 0.159 \\
\hline D06 & $\begin{array}{l}>196 \\
\leq 217\end{array}$ & 1.116 & 0.131 & 1.115 & 0.014 & 1.091 & 0.003 \\
\hline D07 & $\begin{array}{l}>217 \\
\leq 234\end{array}$ & 0,886 & 0.049 & 1.123 & 0.038 & 0.775 & 0.026 \\
\hline D08 & $\begin{array}{l}>234 \\
\leq 253\end{array}$ & 0.860 & 0.048 & 1.213 & 0.015 & 0.976 & No trace \\
\hline D09 & $\begin{array}{l}>253 \\
\leq 270\end{array}$ & 0.194 & 0.032 & 0.643 & No trace & 0.547 & No trace \\
\hline D10 & $\begin{array}{l}>270 \\
\leq 287\end{array}$ & 0.311 & 0.014 & 0.359 & No trace & 0.284 & No trace \\
\hline D11 & $\begin{array}{l}>287 \\
\leq 302\end{array}$ & 0.137 & 0.004 & 0.275 & No trace & 0.143 & No trace \\
\hline D12 & $\begin{array}{l}>302 \\
\leq 317\end{array}$ & 0.089 & No trace & 0.218 & No trace & 0.108 & No trace \\
\hline D13 & $\begin{array}{l}>317 \\
\leq 330\end{array}$ & 0.018 & No trace & 0.060 & No trace & 0.223 & No trace \\
\hline D14 & $\begin{array}{c}>330 \\
\leq 342.7\end{array}$ & 0.004 & No trace & 0.012 & No trace & 0.008 & No trace \\
\hline D15 & $\begin{array}{l}>342.7 \\
\leq 356.5\end{array}$ & No trace & No trace & 0.021 & No trace & No trace & No trace \\
\hline Total & - & 21.18 & 3.18 & 18.98 & 3.28 & 16.86 & 2.61 \\
\hline $\begin{array}{l}\text { Tar in gas } \\
\text { engine } \\
\text { D06-D23 }\end{array}$ & - & 3.615 & 0.278 & 5.039 & 0.067 & 4.155 & 0.029 \\
\hline $\begin{array}{c}\text { Conversion } \\
\text { D06-D23 }\end{array}$ & - & & $2.3 \%$ & & $.6 \%$ & & $.3 \%$ \\
\hline
\end{tabular}


The results with nearly the same experimental conditions are shown in Table 3. The first set of data is taken from Table 2 to facilitate comparison. As can be seen the conversion could be enhanced to over $98.6 \%$ and $99.3 \%$ at reduced flow rates of $15 \mathrm{Nm}^{3} / \mathrm{h}$ and $10 \mathrm{Nm}^{3} / \mathrm{h}$, respectively. In the last experiment the overall tar concentration was $29 \mathrm{mg} / \mathrm{Nm}^{3}$ and less than the goal of $50 \mathrm{mg} / \mathrm{Nm}^{3}$. Notable is the fact that here the fractions D08 to D14 were totally removed and converted. According to the results of the last experiment, the tar concentration in purified syngas was already suitable for IC gas engine use.

\subsection{Discussion of the Results}

The operation temperature of the catalytic reactor was an important parameter for tar conversion. In the experiment at the operation temperature at $700{ }^{\circ} \mathrm{C}$, syngas flow rates turned to be the determining factor. Therefore the affects of syngas flow rates were investigated by measuring the temperatures in catalyst bed and syngas. Three $\mathrm{Ni} / \mathrm{Cr}-\mathrm{Ni} / \mathrm{Si}$ thermocouples were installed at the top, middle and bottom of the catalyst reactor measuring the temperature of raw gas at the entrance, the temperature in the middle of catalyst bed and the temperature of purified gas at the exit, respectively. The deviation of $\mathrm{Ni} / \mathrm{Cr}-\mathrm{Ni} / \mathrm{Si}$ thermocouples was about $\pm 7.5^{\circ} \mathrm{C}$. Figure 5 shows the temperature profiles for the applied flow rates of 20,15 , and $10 \mathrm{Nm}^{3} / \mathrm{h}$.

The first diagram (Figure 5a) demonstrates a dramatic drop of catalyst bed temperature from 700 to $200{ }^{\circ} \mathrm{C}$, nearly equal to the temperature of raw gas. The course of purified gas rose first to $420{ }^{\circ} \mathrm{C}$, dropped to $230{ }^{\circ} \mathrm{C}$ and rose again. This behavior is typical for unsteady flow states between laminar and turbulent flow within the reactor influencing heat and mass transfer. It meant that under the flow rate of $20 \mathrm{Nm}^{3} / \mathrm{h}$, most of the heat from the heating elements was transported by syngas and this resulted in the observed temperature drop of the catalyst bed as well as the temperature rise of the purified gas. The temperature fluctuation of purified gas demonstrated that the syngas flow was unsteady inside the catalytic reactor and hence caused the temperature fluctuation.

Figure 5. Temperatures in catalytic reactor under different flow rates: (a) Syngas flow rate $20 \mathrm{Nm}^{3} / \mathrm{h}$; (b) Syngas flow rate $15 \mathrm{Nm}^{3} / \mathrm{h}$; and (c) Syngas flow rate $10 \mathrm{Nm}^{3} / \mathrm{h}$.

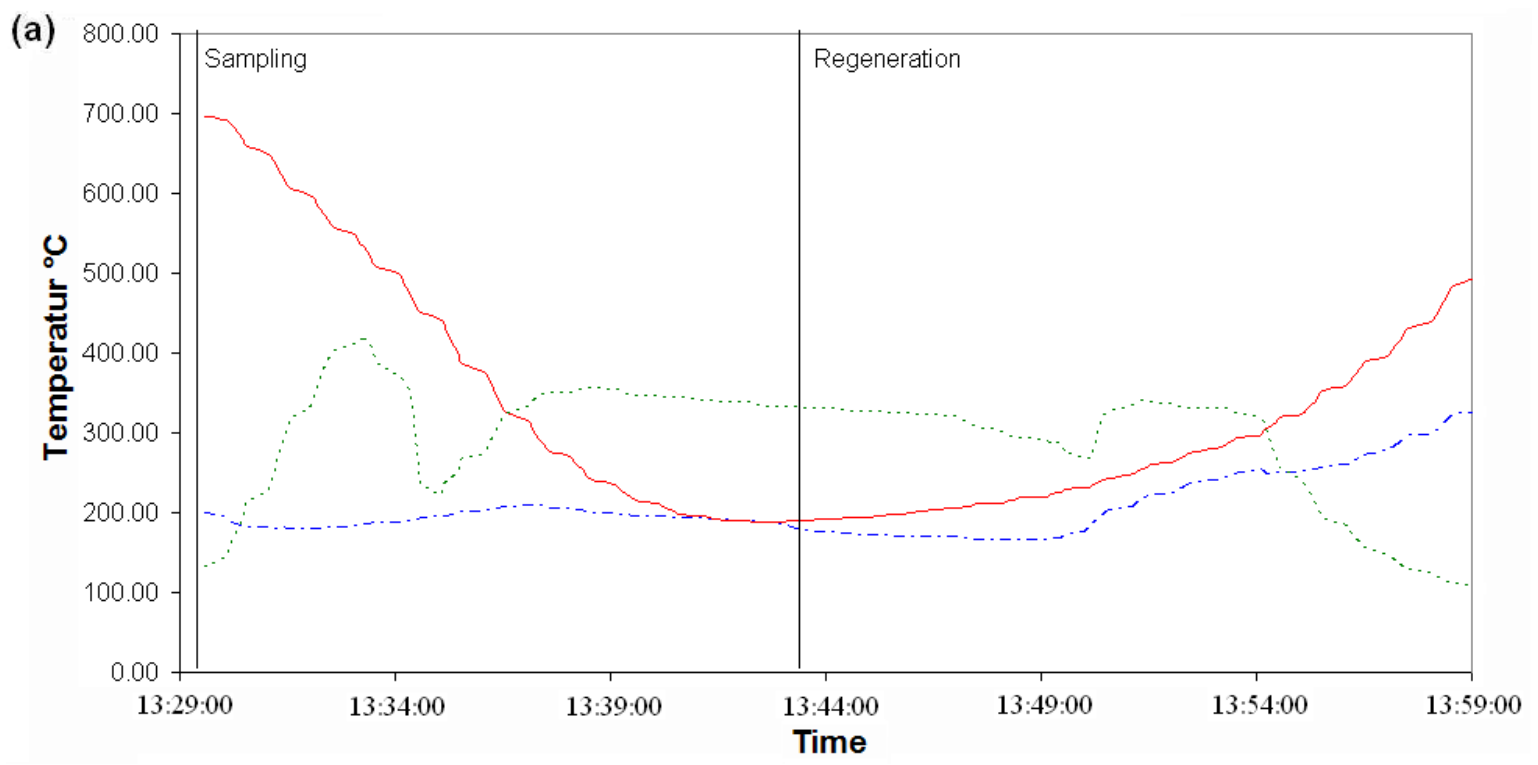


Figure 5. Cont.
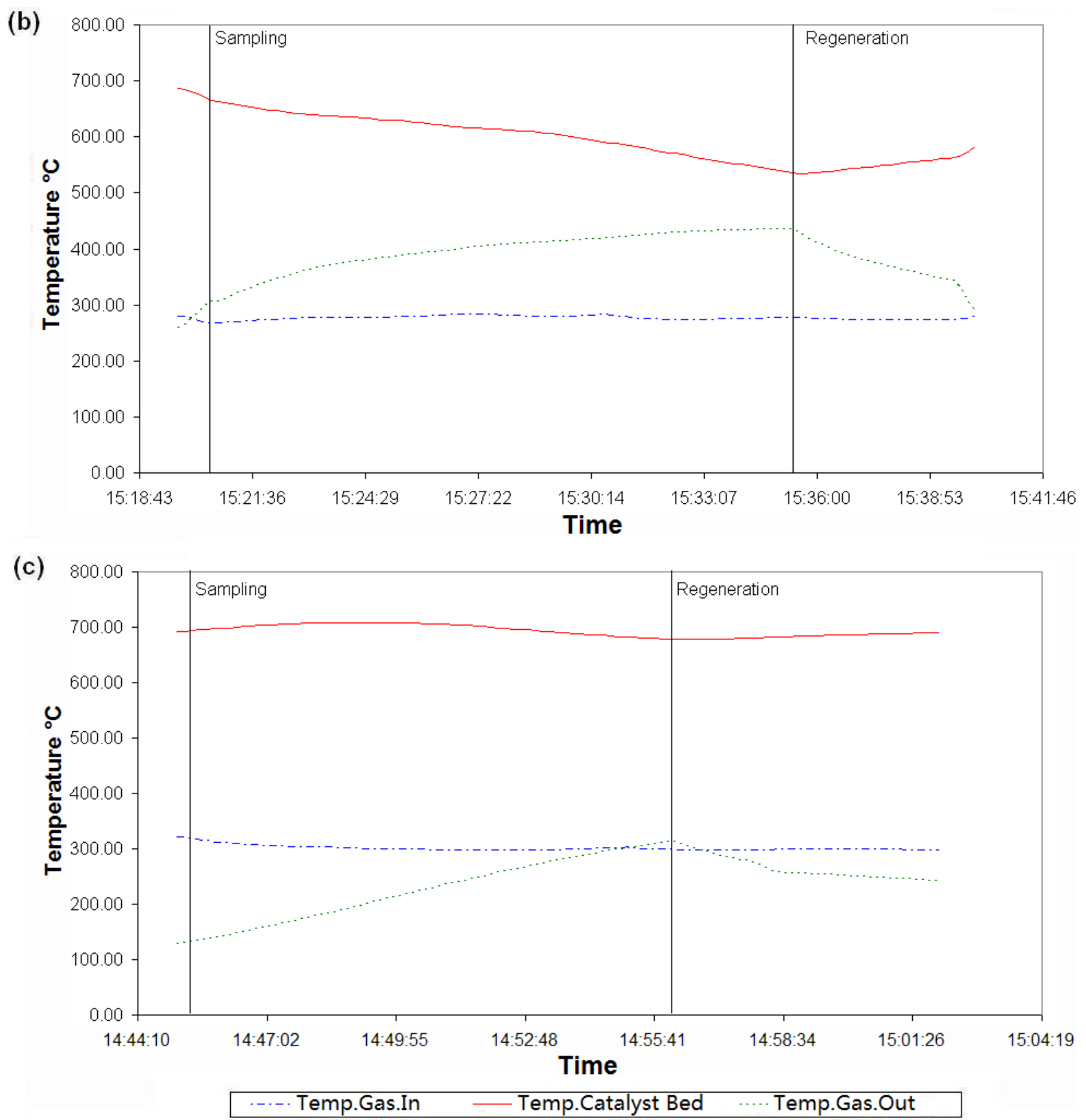

The heat loss of catalyst and the unsteady gas flow disturbed the regular heat and mass transfers in catalytic bed and further leaded to a significant reduction of catalyst activity. Hence the tar conversion during the $3^{\text {rd }}$ cracking process was only $92.3 \%$. Figure 5 b shows that with a reduced flow rate of $15 \mathrm{Nm}^{3} / \mathrm{h}$, the gasifier output temperature rises and the input gas temperature at the reactor is $280{ }^{\circ} \mathrm{C}$. During the $4^{\text {th }}$ hydro cracking process, the catalyst temperature dropped from $700{ }^{\circ} \mathrm{C}$ to about $530{ }^{\circ} \mathrm{C}$. The temperature of purified gas rose gradually to about $400{ }^{\circ} \mathrm{C}$. The rising velocity of purified gas temperature was slower than with the $3^{\text {rd }}$ tar cracking process. It meant the losses of heat and activity in catalyst bed were not so much as the $3^{\text {rd }}$ tar cracking process. The syngas flow was also more stable hence the extent of contact the syngas and the catalyst was also much more efficient than in the $3^{\text {rd }}$ cracking process. Therefore the tar conversion during the $4^{\text {th }}$ cracking process could reach $98.6 \%$ and the tar concentration in purified gas was also reduced significantly to be only $67 \mathrm{mg} / \mathrm{Nm}^{3}$, which almost satisfied the IC gas engine requirements. 
Figure $5 \mathrm{c}$ shows that during the $5^{\text {th }}$ hydro cracking process, with a further reduced syngas flow rate to $10 \mathrm{Nm}^{3} / \mathrm{h}$, the temperature of raw gas rose to about $310{ }^{\circ} \mathrm{C}$. Seven minutes after starting the hydrocracking process, the temperature of catalyst bed rose to about $715{ }^{\circ} \mathrm{C}$ and then dropped to about $680{ }^{\circ} \mathrm{C}$ at the end. The temperature rise of catalyst bed showed that the rate of heat loss during the first 6 min was less than the rate of heat compensation. However, the heat compensation which was provided by heat elements could only heat the catalyst bed to $700{ }^{\circ} \mathrm{C}$, the further rise of $15{ }^{\circ} \mathrm{C}$ was caused by tar conversion reactions, since they are exothermic. Along with the tar cracking process, the soot formation reactions also started and hence the rate of heat compensation was reduced. After seven minutes, the rate of heat compensation became less than the rate of heat loss, and the temperature of the catalyst bed inevitably decreased.

During the $5^{\text {th }}$ purification process the temperature of purified gas rose gradually to about $330{ }^{\circ} \mathrm{C}$ which was only $20^{\circ} \mathrm{C}$ higher than the raw gas. The heat loss caused by gas flow was further reduced and the operating temperature of catalyst was maintained. Therefore during the $5^{\text {th }}$ cracking process a 99.3\% tar conversion could be achieved and the tar concentration in the purified syngas was only $29 \mathrm{mg} / \mathrm{Nm}^{3}$, which already satisfied the technical requirements of IC gas engines. The last experiment had achieved the aim of this work: the overall tar (the fractions of D06-D23) concentration was reduced to less than $50 \mathrm{mg} / \mathrm{Nm}^{3}$.

The D01-D05 fractions in purified syngas could be utilized and increase the calorific value of syngas. The approximate HCV from D01 to D05 are: $47.9 \mathrm{~kJ} / \mathrm{g}, 47.7 \mathrm{~kJ} / \mathrm{g}, 47.56 \mathrm{~kJ} / \mathrm{g}, 47.29 \mathrm{~kJ} / \mathrm{g}$ and $47.23 \mathrm{~kJ} / \mathrm{g}$ [13]. Hence from the third, fourth and fifth experiments, the increases of HCV were: $138.57 \mathrm{~kJ} / \mathrm{Nm}^{3}, 153.47 \mathrm{~kJ} / \mathrm{Nm}^{3}$ and $123.15 \mathrm{~kJ} / \mathrm{Nm}^{3}$. The average calorific value of purified syngas was about 3.6 MJ/ $\mathrm{Nm}^{3}$, hence after the tar purification the quality of syngas were increased 3.4-4.3\%.

\section{Conclusions}

Syngas from woody biomass can be enhanced for utilization in IC gas engines with gas purification using hydrocracking technology. As shown in this paper the requirement for tar concentrations of less $50 \mathrm{mg} / \mathrm{Nm}^{3}$ can be achieved by catalytic hydrocracking based on palladium doped steel turnings. Experiments show the important role of an accurate design and operation strategy. Catalytic temperature and syngas flow rate are the most important factors which directly determine the effect of tar conversion. At an appropriate catalytic temperature, the effect of tar conversion is intensively affected by syngas flow rates. With this technology the interfering tarry components in syngas can be removed and converted into short-chain hydrocarbons, thus increasing the heat value of syngas. This kind of tar purification process can be operated continuously by connecting in parallel more hydrocracking reactors.

\section{Acknowledgements}

The work was supported by BMWi (Bundesministerium für Wirtschaft und Technologie) by the resolution of Deutscher Bundestag within the IGF-framework (Industrial Community Research) administered by AiF under 14398 BG "Entwicklung und Erprobung der katalytisch spaltenden Hydrierung und der katalytischen partiellen Oxidation zur Aufbereitung teerhaltiger Brenngase aus der Biomassevergasung”. The Institute of Energy and Environmental Technology e.V. (IUTA), Duisburg 
with Egon Erich and Bernd Neukirchen from TU Dortmund University are gratefully acknowledged for supporting this work.

\section{References}

1. Lin, Y.; Tanaka, S. Ethanol fermentation from biomass resources: Current state and prospects. Appl. Microbiol. Biot. 2006, 69, 627-642.

2. Caputo, A.C.; Palumbo, M.; Pelagagge, P.M.; Scacchia, F. Economics of biomass energy utilization in combustion and gasification plants: Effects of logistic variables. Biomass Bioenergy 2005, 28, 35-51.

3. Yoshioka, T.; Hirata, S.; Matsumura, Y.; Sakanishi, K. Woody biomass resources and conversion in Japan: The current situation and projections to 2010 and 2050. Biomass Bioenergy 2005, 29, 336-346.

4. Wang, L.; Weller, C.L.; Jones, D.D.; Hanna, M.A. Contemporary issues in thermal gasification of biomass and its application to electricity and fuel production. Biomass Bioenergy 2008, 32, 573-581.

5. Cui, P.; Yan, Y.; Chuang, Z.; Hai, T. Study on the distribution and quantity of biomass residues resource in China. Biomass Bioenergy 2004, 27, 111-117.

6. Demirbes, M.; Balat, M. Recent advances on the production and utilization trends of bio-fuels: A global perspective. Energ. Convers. Manag. 2006, 47, 2371-2381.

7. Bhattacharya, S.; Abdul, S.; Runqing, H.; Somashekar, H.; Racelis, D.; Rathnasiri, P.; Rungrawee, Y. An assessment of the potential for non-plantation biomass resources in selected Asian countries for 2010. Biomass Bioenergy 2005, 29, 153-166.

8. Wang, C.; Du, Z.; Pan, J.; Li, J.; Yang, Z. Direct conversion of biomass to bio-petroleum at low temperature. J. Anal. Appl. Pyrol. 2007, 78, 438-444.

9. Demirbes, A. Progress and recent trends in biofuels. Prog. Energ. Combust. 2007, 33, 1-18.

10. Asadulla, M.; Ito, S.; Kunimori, K.; Yamada, M.; Tomishige, K. Biomass gasification to hydrogen and syngas at low temperature: Novel catalytic system using fluidized-bed reactor. J. Catal. 2002, 208, 255-259.

11. Chen, G.; Andries, J.; Spliethoff, H.; Fang, M.; van de Enden, P.J. Biomass gasification integrated with pyrolysis in a circulating fluidized bed. Sol. Energy 2004, 76, 345-349.

12. Kumar, A.; Jones, D.D.; Hanna. M.A. Thermochemical biomass gasification: A review of the current status of the technology. Energies 2009, 2, 556-581.

13. Devi, L.; Ptasinski, K.J.; Jenssen, F.J.J.G. A review of the primary measures for tar elimination in biomass gasification processes. Biomass Bioenergy 2003, 24, 125-140.

14. Erich, E. Decentralized Gasification of Biomass-Variant Processes to Produce Low-Tar Product Gases from Biomass. In Energy from Waste, 1st ed.; Thomé-Kozmiensky, K.J., Beckmann, M., Eds.; TK-Publishing Inc: Nietwerder, Germany, 2007; pp. 503-518.

15. Senger, W.; Schöppe, G.; Erich, E. State of the gasification technology for the utilization of bio fuels in example of wood. Eur. J. Wood Prod. 1998, 56, 67-74.

16. Li, C.; Hirabayashi, D.; Suzuki, K. Steam reforming of biomass tar producing $\mathrm{H}_{2}$-rich gases over $\mathrm{Ni} / \mathrm{MgO}_{\mathrm{x}} / \mathrm{CaO}_{1-\mathrm{x}}$ catalyst. Bioresour. Technol. 2010, 101, 97-100. 
17. Marutzky, R.; Seeger, K. Energy from Wood and Biomasses, 1st ed.; DRW Publishing Inc.: Stuttgart, Germany, 1999; pp. 20-112.

18. Saxena, R.C.; Seal, D.; Kumer, S.; Goyer, H.B. Thermo-chemical routes for hydrogen rich gas from biomass: A review. Renew. Sustain. Energy Rev. 2008, 12, 1909-1927.

19. Bajohr, S.; Hoferer, J.; Reimert, R.; Schaub, G. Thermo-catalytic conversion of hydrocarbons from biomass pyrolysis and gasification. Proc. DGMK 2002, 2, 167-174.

20. Jones, D.; Pujado, P. Handbook of Petroleum Processing, 1st ed.; Springer-Verlag: New York, NY, USA, 2006; pp. 30-144.

21. Aznar, M.; Caballero, M.; Gil, J.; Martin, J.; Corella, J. Commerical steam reforming catalysts to improve biomass gasification with steam-oxygen mixtures. Ind. Eng. Chem. Res. 1998, 37, 2668-2680.

22. Gartner, B.; Kuchling, P.; Chudzinski, S. Catalytic cracking of long chain hydrocarbons in raw gas of wood coking. Proc. DGMK 2002, 2, 159-165.

23. Mckendry, P. Energy production from biomass (Part 3): Gasification technologies. Bioresour. Technol. 2002, 83, 55-63.

24. Jess, A.; Depner, H. Thermo-catalytic purification of raw gas from the gasification and coking of solid fuels. Chem. Eng. Technol. 1997, 69, 970-973.

(C) 2011 by the authors; licensee MDPI, Basel, Switzerland. This article is an open access article distributed under the terms and conditions of the Creative Commons Attribution license (http://creativecommons.org/licenses/by/3.0/). 